\title{
THE MEDIEVAL HOSPITALS \\ OF BURY ST. EDMUNDS
}

by

\section{JOY ROWE}

A GENERAL survey of the history of the Benedictine abbey of St. Edmund in Suffolk produces very little material which sheds light on the place and development of medical institutions and practice in the mother house and its dependencies. It is, perhaps, characteristic of the relationship between the religious house and the town which had grown up in its shadow and flourished as its associate, that it was not until the last of the monastic hospitals had been dissolved and its revenues diverted to a less charitable end, that the inevitable material consequences were fully apparent to the layman. The townsfolk, finding themselves destitute of any kind of relief in old age or physical adversity, drew the immediate and just conclusion that these needs had previously been met by the abbey, whose downfall they had watched without any apparent regret. Attached to the Chantry Certificates for $1544-5,{ }^{1}$ which give details of the value of the hospitals at the time of their dissolution and of their subsequent disposal by the Crown, there is a petition from the inhabitants of Bury St. Edmunds that

it may please the King's most excellent Majesty of his most charitable benignity, moved with pity, in that behalf to convert the revenues and profits of the sum of the said promotions [the hospitals] into some godly foundation, whereby the said poor inhabitants daily there multiplying may be relieved.

The early history of the abbey contains a number of allusions which indicate the close association of mind, body and spirit so characteristic of the thought of the Middle Ages. A brief survey of the more notable points of medical interest may not be misplaced here. In 1020 a small community of Benedictine monks assumed the guardianship of the shrine of St. Edmund, which had become notable for the favours obtained there. The saint had been martyred in the late ninth century by the Danes, but this did not prevent Cnut, the Danish king, from having a great devotion to him. As an act of piety he freed the monks and the town of St. Edmund from royal taxation. ${ }^{2}$ His example, however, failed to influence his successor, Swein, who, as a pagan, honoured neither the exemption granted by his predecessor nor the shrine itself. The king is reported to have visited the town to receive the taxes due to him, ignoring the warnings of the guardians of the shrine, even poking a disrespectful finger through the interstices of the surrounding screen. No one was in the least surprised when his arm immediately wasted and became useless. Nevertheless, Swein evidently had the courage of his lack of conviction and, in spite of warnings, pressed his demands for the payment of the taxes. It must have been 
with considerable relief that both monks and townsfolk heard of his death in an appropriately short time- 'tacitu manu sancti, miserabiliter extinctus est'. ${ }^{3}$ In spite of this unpromising start, however, the shrine of St. Edmund was held in high esteem for the miracles of healing wrought there, and up to the eve of the suppression of the monastery pilgrims made their way there to seek a blessing at the shrine and to drink from the cup of St. Edmund. ${ }^{4}$

Baldwin, third abbot of St. Edmund, was before his election a notable court physician, in attendance upon Edward the Confessor and later, in a consultant capacity, upon William I. He was able to use his skill to obtain practical benefits for his abbey, though in a manner which modern medical ethics would consider unsuitable. After returning from Rome with a Papal Bull freeing St. Edmund's Abbey from episcopal visitation, he received information that the local bishop, Arfast of Norwich, was intending to challenge the decision. As he was journeying to the abbey, the bishop's mount passed under a tree, one of whose branches pierced his eye, causing great pain and immediate blindness. Baldwin rode out to meet the injured bishop, brought him to his own lodging and invited him to renounce his rights of visitation in exchange for treatment of his eye. Arfast is said by the chronicler to have agreed to this proposal and Baldwin immediately assumed the role of physician.

Cauteries and colliriums were applied to his eye, producing first a painful suffusion of blood and then blindness. The darkness fortunately dispersed in due course and only a small obscurity remained in the pupil..$^{5}$

\section{In I 180 Abbot Hugh I died after a riding accident:}

The knee-pan lodged in his ham, physicians came upon him and sorely tormented him but they healed him not. Being removed to Bury his thigh mortified and the disorder mounted to his heart. The pain brought on a tertiary fever and on the fourth fit he expired. ${ }^{6}$

His successor as abbot was Samson, whose tenure of office is described in intimate detail in the chronicle of Jocelin of Brakelond. ${ }^{7}$ Jocelin remarks that Samson kept his finger on the pulse of the monastery by making frequent visits to the room in which the monks were permitted to relax after their statutory periodic blood-letting. The gossip overheard there, induced by the unaccustomed warmth and ease, enabled him to learn many secrets which otherwise might have remained unknown to him. ${ }^{8}$ During his abbacy Walter of St. Albans, a well-known physician, gave a large sum of money acquired from successful practice towards the building of a new almonry for the reception of indigent strangers. ${ }^{9}$ This may soon have been in considerable demand for, in 1257, the town and monastery suffered heavy losses during a severe outbreak of plague in which more than a thousand of the townsfolk alone died.10 A century later the Black Death swept through the country, and Suffolk suffered losses comparable with the rest of the country. So severe was the mortality in the abbey that Clement VI issued a Bull permitting the ordination to the priesthood of men of twenty years-five years below the canonical age-in 


\section{The Medieval Hospitals of Bury St. Edmunds}

order to maintain the choir offices and daily Mass in the abbey. ${ }^{11}$ It may not, perhaps, be irrelevant here to look at the religious chronicler as a scientific witness. In the mid-fourteenth century a Franciscan friar, living somewhere in the custody of Cambridge-possibly at Babwell on the outskirts of Bury St. Edmunds-added increasingly detailed notes of national and local events to his friary's copy of a standard East Anglian chronicle. ${ }^{12}$ His interest is shared equally between the wars with France and Scotland and the local crops and weather. In 1348 he writes of the coming of a couple of ships to Melcombe in Dorset, one of which had Bristol as her port of origin and amongst whose crew was a Gascon sailor, already sick of the Black Death. The infection spread to the townsfolk, the first victim dying on 23 June after three days' illness. This circumstantial contemporary observation antedates by several weeks the conjectural dates of outbreak advanced in later work on the Black Death. ${ }^{13}$ In the next year the annalist records the entry of the plague into the Cambridge custody at Eastertide and its continuing there for the rest of the year. The record then breaks off for seven years and is taken up in a different hand with an account of the plague arriving in London at Michaelmas. In this outbreak the first victims were a large number of children, but the mortality among adults rose after Easter. In the next year, 136r, the annalist remarks that although the plague was much less severe in the south, yet many children and young people died. It is this first-hand information that warms and enlivens the dry bones of the history of monastic hospitals, and it is with this in mind that we now turn to the institutions.

The hospital of the Middle Ages was primarily an ecclesiastical institution, designed for the refreshment of the soul rather than for the relief of physical suffering. ${ }^{14}$ Its precise nature varied with the needs of the time. During the century following the Conquest the title of Hospital was given to guest-houses within the precincts of a religious house; there the guests were received accordto the rule of St. Benedict 'as if they were Christ himself'. These guests were for the most part casual, occasional travellers: other accommodation was available for regular wayfarers. Rooms were set aside in the apartments of the senior monastic officials for the upper classes, whereas pedlars and other regular itinerants probably found the local alehouse more congenial.

In the later twelfth century and for the next hundred years the practice of pilgrimage made a real mark on the life of the countryside, so that guest-house hospitals, often associated with an infirmary, sprang up along the routes. St. Edmund's Abbey, as well as being a centre of pilgrimage in its own right, stood on one of the main ways to the great shrine of Our Lady of Walsingham. After 1270 the regular practice of pilgrimage declined, though special anniversaries and great events still brought vast crowds; as late as 1420 , I00,000 pilgrims made the journey to Canterbury for the jubilee solemnities and needed to be lodged and cared for all the way along the routes as well as in the city itself. In general, however, the number of travellers was diminishing, partly as a result of the action taken by the government to check vagrancy and partly through a diminution in the number of foreign visitors. 
The function of the monastic hospital was not confined to the exercise of hospitality; provision was also made for the feeding and clothing of the indigent and the aged and for the care of the sick. The tramps were given temporary shelter in the monastic guest-house, but the incurably sick and the aged were received as permanent members of an associated community, living together under the discipline of a rule of life designed to prepare the pilgrim soul for the stronger air of its heavenly country. In the early days of a religious house this community was housed within the precincts, but as the mother house expanded, separate buildings were established outside its walls but still under its supervision. This loose connection also characterized the administration of the new hospitals, each of which possessed a certain degree of autonomy, in that each had its own dedication and particular rule, but was still united to the mother house in all external and major affairs through having no seal of its own. The daily administration of the typical hospital was in the hands of a master who was appointed from the professed monks of the mother house and accountable to the hospitaller, who had the general oversight of all the hospital communities.

Very little therapeutic medicine was practised in the majority of hospitals. The inmate's daily life approximated much more closely to that of the modern almshouse than to that of a hospital. Lepers alone were singled out for particular treatment, and this distinction was the result of anxiety to check the spread of this dreaded disease in the local community rather than from any ability either to arrest its course or to alleviate its symptoms. It is clear that the leprosy of the Middle Ages was very much more than a categorical term for any intractable skin complaint. A leper was in every sense outcast from healthy society: he was literally considered as dead. As soon as the diagnosis had been confirmed the sick man entered the parish church for the last time while a quasi-Requiem Mass was offered for him. This was completed by the shovelling of earth over his feet to signify his burial and he was expelled from the community. So prevalent was the disease in the twelfth century that it was impossible for many lepers to obtain admission to a leper hospital, or lazar house, and they were condemned to a life of solitude. The foundation of a leper hospital was regarded as a most desirable act of piety, and the high proportion of these foundations -200 out of a total of about 750-is an indication not only of the prevalence of the disease but also of the Church's concern with this social problem. It has been suggested that the spread of leprosy was aggravated by the Crusades: certainly it was widespread in England from the twelfth to the middle of the fourteenth century when its incidence suddenly declined and gradually disappeared. This may be yet another feature of the national life shaped or modified by the Black Death. It is possible to explain, at least in part, the decline in the incidence of leprosy and in the number and size of lazar houses after I350, as a result of the years of pestilence which must have added to the already wretched life of the leper the fear of dying from plague in his solitude. With the resulting sudden fall in population, contributions to the upkeep of hospitals decreased and the high cost of living, taken in conjunction with the

$$
256
$$




\section{The Medieval Hospitals of Bury St. Edmunds}

fall in the value of land endowments, produced a grave economic problem for the smaller houses.

Whatever the physical condition of the inmates, the administration of the hospitals of the Middle Ages followed the same pattern. The life of the community was regulated by a semi-monastic rule which placed special emphasis on the Liturgy and on the common recitation of at least part of the daily office. The rule of canonical obedience was laid explicitly on each individual, a most necessary provision in community life into which were grafted members who had grown old each following his own will. The warden of the hospital exercised his jurisdiction over the personal lives of the members as well as over the administration of the estates and the equipping of the house. In the case of dependent hospitals the accounts were exhibited at the great annual audit at the mother house, but the actual moneys were not merged with the general funds. Taxation lay less heavily on the hospitals than on other religious foundations since they were exempt from the payment of Papal Xths.

The six hospitals of Bury St. Edmunds were all dependent on the abbey and formed part of the provision made by the religious community for the welfare of its own sick and aged members as well as that of its lay neighbours. St. John's Hospital, also known as Domus Dei, Maison Dieu, Mayson Deuze, or God's House, lay at the south gate of the town. ${ }^{15}$ It was founded about 1216 by Abbot Edmund, and placed under the general supervision of the prior, although the practical responsibility of its running came within the province of the almoner. The foundation deed expresses the purpose of the hospital to be the sheltering of seven genuinely destitute men. ${ }^{16}$ The warden was given discretionary powers to admit other deserving cases and to care for those who fell sick during their stay in the hospital until they were fit to be sent on their way.

Precepimus ut de bonis ipsius Domus Dei soli pauperes mendicantes . . . hospitentur et recreantur. Et si ibidem pauperes aliqui hospitati in gravem egritudinem deciderunt nec unde decedere possunt exhibeant secundum vires et facultates dicte Domus Dei et cum fuerint reparati discedant et incedant in viam.

It was evidently not intended that the hospital should provide a permanent home for beggars, for the foundation deed expressly forbids the setting up of an altar while still encouraging the household to private prayer:

$\mathrm{Nec}$ in dicte Domo Dei missa celebretur nec altare erigatur sed solis oracionibus privatis vacent qui ibidem propter hospitalitatis et recreacionis beneficium confluxerint.

The hospital evidently met a real need for within twenty years Abbot Simon of Luton ordered its removal to a larger site and gave permission for a chapel and cemetery to be added. ${ }^{17}$ A proportion of the revenue of the hospital was derived from land let out to farm in the town and surrounding countryside. In I 340 the tax on sheaves and fleeces for which the hospital was liable to the Crown was assessed upon 12 acres. ${ }^{18}$ Further revenue accrued from the chantry of the Cockerell family which was established in the hospital chapel in $1379 .{ }^{19}$ 
The chantry priest's stipend of $33^{s} .4 d$. was augmented by the provision of board, lodging and firing and the total sum was reckoned to be part of the assets of the hospital.

Closely associated with St. John's Hospital, both in its situation and in its intention, was St. Petronilla's Hospital.20 The saint herself, traditionally St. Peter's daughter, was held in considerable veneration throughout the eastern counties. Her skull was preserved among the abbey treasures, and it is recorded that Henry III borrowed a reliquary from Norwich Cathedral containing 'of St. Petronilla one piece'. ${ }^{21}$ The hospital was founded in the twelfth century outside the south gate, originally as a refuge for female lepers, but was refounded in the fifteenth century to serve the poor. The closeness of the hospital to Domus Dei may have led to a convenient consolidation of the two foundations, at least for some administrative purposes, for in I294 a taxation assessment is headed 'God's House, called St. Pernell's, Southgate Street'..22 The Valor Ecclesiasticus of I 535 gives the annual net income of St. Petronilla's as $£$ IO I $7 s$. I $\frac{1}{2} d$., with a further $£ 4$ IIs. $8 d$. earmarked for distribution to the poor in the house. ${ }^{23}$

During the latter part of the last century the last remaining part of St. Petronilla's Hospital, a traceried window, was removed from the site and incorporated in the ruins of St. Nicholas's Hospital. ${ }^{24}$ This house was established outside the town's east gate by Abbot Hugh of Northwold about the year 1215 and was clearly intended to be of the almshouse type. ${ }^{25}$ The original establishment consisted of a master, a chaplain and a number of brethren and the community was sufficiently stable to be able to resist any attempt to alter its character. In I 301 an attempt was made to widen the scope of the hospital to include lepers, but this came to nothing, and in 1325 a chantry was established in the hospital chapel, no doubt a more agreeable source of revenue. Although the chantry revenue was reckoned as belonging to the hospital it can in fact have brought little to the house, as the office of stipendary priest was held as a sinecure by one of the abbey's major obedientaries. In spite of this the hospital was comparatively well endowed and in addition enjoyed the profits of a two-day fair. Local wills also show a certain tenderness towards the house, for in I 506 Henry Rudd, M.D., left to it a set of white satin vestments, embroidered with St. Nicholas's arms, to the value of 5 marks, and in 1535 Ann Buckenham, a tenant of the hospital, bequeathed to the chapel a small chalice. In the same year the Valor Ecclesiasticus shows that the mastership and chaplaincy were held by the same man, and the annual net income is given as $£ 6$ Igs. I $d$. This seems to reflect a decline in prosperity, for in 1340 the hospital derived part of its income from the not inconsiderable holding of 44 acres. ${ }^{26}$

The lepers who were rejected by the inmates of St. Nicholas's Hospital may well have tried to gain admission to the official lazar house, St. Peter's Hospital. ${ }^{27}$ This was situated on the main road into the town near the Risby Gate. The original intention of its founder, Abbot Anselm, was to provide a refuge for infirm and leprous priests but, understandingly enough, candidates for admission seem to have been drawn entirely from the latter category. The hospital 


\section{The Medieval Hospitals of Bury St. Edmunds}

was well endowed, and in 1535 showed an annual net income of $£$ IO I 8 s. I0 $\frac{1}{2} d$. and an additional $£ 4$ for distribution inside the house. This may have derived from the charitable gift of Scientia de la Gaye who founded a chantry in the hospital, making over to the master an annual rent of Ios. to be used to pay the stipend for a weekly Requiem and to buy shoes for the inmates. In common with the other hospitals, proctors were appointed to collect alms from the congregations in the parish churches, and in 1538 the community authorized the collection of alms for the hospital throughout the country.

It has been considered that St. Peter's Hospital was not dissolved with the mother house and the other hospitals in $1539 .{ }^{28}$ The Chantry Certificates for I544-5 give the particulars:

One other Hospital called St. Peter's, lying without Risbygate Street in Bury now dissolved by the license of our late Sovereign Lord King Henry VIII and granted to the said Sir George Somerset, Knight, by the said Letters Patent.29

The Bury St. Edmunds Corporation muniments include a conveyance dated 25 September 1545 , recording the sale of 'the late chapel and hospital of St. Peter' for $£_{1}$ I 7 IOs. od. ${ }^{30}$ The petition of the townsfolk already cited, taken in conjunction with the Chantry Certificates, is a clear indication that none of the hospitals did in fact escape.

According to the $182 \mathrm{I}$ edition of the Monasticon, a hospital dedicated to St. Stephen stood between the east gate bridge and St. Nicholas's Hospital. ${ }^{31}$ The abbey possessed 'certain drops of St. Stephen's blood which sprung from him at such time as he was stoned', but apart from these meagre facts nothing is known of the hospital. As almoner of the primitive church, St. Stephen was considered to be a most efficient patron of the sick so although the foundation is so slenderly documented, its existence is fully credible.

The most notable of the six hospitals was dedicated to St. Saviour, and its history well repays consideration. ${ }^{32}$ The hospital was founded by Abbot Samson in about 1184 outside the north gate, but the endowment was not confirmed until the reign of John. There is a persistent local tradition that John himself founded a hospital in the town; Bale, in his play King Fohn, remarked that 'this foundation maketh him to be a man of notable mercy' - an unusual tribute to John. ${ }^{33} \mathrm{It}$ is possible that the late confirmation of the original foundation deed may explain this. The original establishment consisted of a master, two chaplainpriests, six clerks, twelve poor men and twelve poor women, thus catering both for the aged clergy and the aged poor. ${ }^{34}$ With his characteristic appreciation of practical necessities Samson not only endowed the hospital liberally with lands and rents but also ensured a proper water-supply from a specially built conduit. ${ }^{35}$ In 1291 the possessions of the hospital were assessed for taxation at the considerable sum of $£_{\mathrm{IO}^{36}}$ and in $\mathrm{r} 34^{\circ}$ its land holdings amounted to 100 acres. ${ }^{37}$ The profits of a one-day fair had also been allowed to the hospital and brought in a considerable income. ${ }^{38}$

The original foundation charter of the hospital defined its purpose as the 
relief of Christ's poor. ${ }^{39}$ This was originally interpreted to include both men and women, but by the end of the thirteenth century the poor women had been replaced by twelve sick monks. ${ }^{40}$ The number of monks received was further augmented in I 30 I by Abbot John of Northwold, who arranged that the monks who staffed his chapel of the Charnel should retire to St. Saviour's. ${ }^{41}$ The fourteenth century saw the hospital involved in a lawsuit with the Crown over a corrody. ${ }^{42}$ This was the Crown's forcible imposition on the hospital of a permanent non-paying guest - a convenient means of disposing of pensioners. As the suit ended favourably for the hospital, the abbot took into his own hands the privilege of admitting pensioners, and a number of men were received, furnished with board and lodging during their lifetime and provided annually with a gown, shoes and stockings in return for a considerable voluntary donation. In 1392 such a pensioner paid 26 marks towards the building costs of a new part of the hospital. ${ }^{43}$ At this time vigorous measures were being taken to reform the constitution and enlarge the premises of the hospital. The effect of the reforms was to transform it, in effect, into a highly organized free chapel. The hospitaller of the day, Walter de Tottington, drew up a detailed rule for the inmates which laid stress on choir offices, the daily offering of Mass by each priest-inmate and the making of appropriate memorials for the founders and benefactors of the hospital. ${ }^{44}$ It was proper that the commemoration of the hospital's benefactors should be laid upon the inmates, for the original endowments had been generously increased by successive generations until by this date the hospital held very considerable estates. A number of lay officials were employed in the administration of the hospital's possessions, and the revised rule attempted to graft them into the corporate life of the house by requiring them to join the brethren at meals in the refectory on certain specific occasions. So detailed were the new regulations that they legislated for the recreation of the inmates as well as for the working hours: on days of solemn Requiem no recreation other than a gentle walk in the surrounding fields was permitted. A real effort was on hand to revive the ideal of community life, for special emphasis is laid on all common activities, whether in the form of punctual attendance at services or in the distribution of the daily allowance of beer after the common meal in the refectory. It seems probable that by this time the lay inmates had been replaced by more monks. The ceremony of reception charges the postulant with the duty of obedience to the abbot and requires the community to agree to his admission. ${ }^{45}$ The commitment on either side is clearly intended to be lifelong. A memorandum of the same date also provides for the expulsion of any who proves himself boastful, quarrelsome, obstinate or a public scandal. ${ }^{46}$

Little direct information has been left which throws light on the daily life of the hospital, but it is possible to reconstruct a few items from the various expenditures and sales mentioned in the account rolls. Necessarily, the main body of expenses both of the claviger, the lay overseer, and of the hospitaller are concerned with major items: rents, repairs to property, the buying and selling of farm stock and produce-but the domestic details are there toowages paid, clothes and liveries bought, shoes mended, the provision of extra 


\section{The Medieval Hospitals of Bury St. Edmunds}

milk on a special occasion. Details of the furnishings of the house are supplied by the list of losses suffered by the hospital in the riots of $1327::^{47}$ six silver spoons, two tablecloths, and a large basin figure among the losses. The legacies of a chaplain-inmate of the early sixteenth century add a touch of colour: two sets of bedclothes with four pillows, a set of green hangings and a coverlet, a red and-white coverlet, scarlet window curtains and a salt cellar. His wardrobe included three cloaks, two of purple, of which one was lined with white fur and the other trimmed with black, and a third blue and bicoloured, his russet clerk's hood and, the crowning touch, a bright red hat. ${ }^{48}$ By way of recreation on suitable days the inmates were evidently allowed to play bowls, for the hospitaller's accounts mention the purchase of twelve bowls for the brethren's recreation. ${ }^{49}$ The more intellectual pursuits were evidently not forsaken in the hospital, for a former inmate bequeathed to the library his copy of the Speculum Humane Salvatoris. ${ }^{50}$

At the same time as he instituted these reforms in the life of the hospital Walter de Tottington was also engaged in the furnishing, if not actually in the building, of a new chapel dedicated to St. Thomas the Martyr. His accounts for 1372 mention the chapel of Our Lady, presumably incorporated within the other hospital buildings. In I 386 the accounts show a large deficit on account of the large sums spent in furnishing the new chapel of St. Thomas. The items listed include one reredos, one canopy, one frontal, two curtains, two altar cloths, two corporals, two towels, two ribboned cushions for the Missal and Gospels, three rubricated books of the Proper, Life, Passion and Miracles of St Thomas and a silver collecting box to stand under the feet of his image on the right side of the altar. The whole chapel was paved with new tiles specially brought from Long Melford. ${ }^{51}$

Thus the hospital expanded and at the same time fell deeper and deeper into debt. In spite of this the buildings were evidently extended throughout the next half century for, in 1447 Humphrey, Duke of Gloucester spent the days between his impeachment at the Bury Parliament and his mysteriously sudden death at the hospital, within its shelter, no doubt with a considerable retinue. ${ }^{52}$ Generous though the endowments of the hospital may have been, they were not intended to answer the call of charity on this scale. Eventually, in I528, by a Bull of Clement VII its finances were taken into the Abbot's private exchequer and the revenues employed for the upkeep of the Abbot's table-a far cry from the relief and refreshment of the poor. ${ }^{53}$ When some eleven years later the mother house was dissolved and its possessions passed to the Crown, St. Saviour's Hospital was involved in the general ruin. In I 542 the site and buildings (excluding the lead from the roof) was granted to Sir John Williams and Anthony Stringer, who in turn alienated to Nicholas Bacon. ${ }^{54} \mathrm{He}$ made use of the materials in the building of his great mansion at Redgrave, ${ }^{55}$ while the lands formerly belonging to the hospital were split up among a number of owners. It is characteristic of the memory of the countryside that the descriptive particulars of these lands retained the name of St. Saviour for generations after the dissolution of the hospital. ${ }^{56}$ Nor did the town of 


\section{Foy Rowe}

Bury St. Edmunds quickly forget these charitable houses. The petition to which reference has already been made contrasted the use made of the tithes in the time of the abbey's greatness with that of the new lay landlords who 'do now take the whole yearly revenues and profits and distribute no part thereof to the aid, comfort or relief of the said poor people'. In spite of their petition to the king and the 'three thousand housling people' who might become a charge on this 'great and Populous town', two and a half centuries elapsed before the hospitals of the abbey of St. Edmund were replaced by a new hospital for the care of the sick in the county of Suffolk. ${ }^{57}$

\section{ACKNOWLEDGEMENTS}

My gratitude is due to the Earl of Iveagh, K.G., K.C.M.G., for permission to make extensive use of the collection of Suffolk MSS. at Elveden and to Mr. William Speed, the custodian of the collection, who has extended every consideration and facility to me over a long period of research; to Martin Statham, Esq., M.A., West Suffolk Archivist, for his assistance in dealing with the archives of the Abbey and Borough of Bury St. Edmunds; to Professor Alan Simpson of the University of Chicago, for the reference to the Bacon MSS. Collection of the University of Chicago.

\section{REFERENCES}

I. Public Record Office, $E_{301} / 45$.

2. Morant, 'On the Abbey of St. Edmund', Proc. Suffolk Institute of Archaeology, vol. rv, I869.

3. West Suffolk Record Office, A8/1.

4. W.S.R.O., A6/1/17. The accounts of the Keepers of the Shrine of St. Edmund show a stipend paid for the administration of the cup of St. Edmund to pilgrims.

5. Y ATES, History of Bury, 1843 , p. 99.

6. Туммs, 'Notes towards a Medical History of Bury', Proc. S.I.A., vol. I, I865.

7. Chronicle of Focelin of Brakelond, edited by H. E. Butler, 1949.

8. Тчммs, op. cit.

9. Туммs, op. cit.

10. Туммs, op. cit.

II. Ritchie, 'The Black Death at St. Edmund's Abbey', Proc. S.I.A., vol. xxvir, 1955.

12. B.M. Add. MS. 47214.

13. GASQUE T, The Black Death in 1348-1349, 1908, gives the date of outbreak as in the autumn of $1348^{\prime}$. B.M. Add. MS. 47214 is specific on the date and source of the outbreak.

14. The pioneer work on medieval hospitals remains that of Miss R. M. Clay, Medieval Hospitals of England, 1909. I am glad to express my debt to her work, especially in this introductory section.

15. Victoria County History, Suffolk II, Cox, 1907, p. 133 .

I6. W.S.R.O., $\mathrm{E}_{2} / 4 \mathrm{I} / 4$.

17. W.S.R.O., $\mathrm{E}_{2} / 4 \mathrm{I} / 4$.

18. W.S.R.O., B6/3/1.

19. V.C.H., op. cit., p. 133.

20. V.C.H., op. cit., p. 135 .

21. GLAY, op. cit., p. 256.

22. W.S.R.O., $\mathrm{A}_{4} / 1$.

23. V.C.H., op. cit., p. 135.

24. Dickinson, Suffolk, 1957, p. 107.

25. V.C.H., op. cit., p. 135 .

26. W.S.R.O., B6/3/r. 


\section{The Medieval Hospitals of Bury St. Edmunds}

27. V.C.H., op. cit., p. 135 .

28. V.C.H., op. cit., p. 135. KNowles and HADcock, Medieval Religious Houses of England and Wales, 1953, p. 260.

29. P.R.O., E301 $/ 45$.

3o. W.S.R.O., E6/1/16.

31. Glay, op. cit., pp. 255, 321 .

32. V.G.H., op. cit., p. 135 .

33. Clay, op. cit., p. 72.

34. Bevan, 'Foundation Deed of St. Saviour's Hospital', Proc. S.I.A., vol. vi, 1885.

35. Burdon, 'St. Saviour's Hospital', Proc. S.I.A., vol. xLX, 1927.

36. W.S.R.O., A4/r.

37. W.S.R.O., B6/3/1.

38. BURDON, op. cit.

39. BeVAN, op. cit.

40. BURDON, op. cit.

41. V.C.H., op. cit., p. 136.

42. BEVAN, op. cit.

43. V.C.H., op. cit., p. 136.

44. Iveagh Collection of Suffolk MSS.

45. Iveagh MSS.

46. Iveagh MSS.

47. V.G.H., op. cit., p. 136 .

48. Iveagh MSS.

49. W.S.R.O., A6/1/16.

50. Iveagh MSS.

51. W.S.R.O., A6/1/16.

52. V.C.H., op. cit., p. 66.

53. V.G.H., op. cit., p. 136.

54. V.C.H., op. cit., p. 136.

55. Redgrave Building Accounts, Bacon MSS., University of Chicago.

56. e.g. I 593. St. Saviour's Farm, Westley, Hengrave MSS., Cambridge University Library.

57. Whiте, Suffolk, 1844, p. 642 . This gives a brief account of the founding, in 1826 , of the present West Suffolk Hospital. 